6-7-2017

\title{
Migrant Workers and Fissured Workforces: CS Wind and the Dilemmas of Organizing Intra-Company Transfers in Canada
}

Eric M Tucker

Osgoode Hall Law School of York University, etucker@osgoode.yorku.ca

Source Publication:

Economic and Industrial Democracy

Follow this and additional works at: https://digitalcommons.osgoode.yorku.ca/scholarly_works

Part of the Labor and Employment Law Commons

(c) (1) $(9)$

This work is licensed under a Creative Commons Attribution-Noncommercial-No Derivative Works 4.0 License.

\section{Repository Citation}

Tucker, Eric M, "Migrant Workers and Fissured Workforces: CS Wind and the Dilemmas of Organizing Intra-Company Transfers in Canada" (2017). Articles \& Book Chapters. 2600.

https://digitalcommons.osgoode.yorku.ca/scholarly_works/2600

This Article is brought to you for free and open access by the Faculty Scholarship at Osgoode Digital Commons. It has been accepted for inclusion in Articles \& Book Chapters by an authorized administrator of Osgoode Digital Commons. 


\title{
Migrant Workers and \\ Fissured Workforces: \\ CS Wind and the Dilemmas \\ of Organizing Inter-Company Transfers in Canada ${ }^{1}$
}

\begin{abstract}
Canadian temporary foreign worker programs have been proliferating in recent years. While much attention has deservedly focused on programs that target so-called low skilled workers, such as seasonal agricultural workers and live-in caregivers, other programs have been expanding, and have recently been re-organized into the International Mobility Program (IMP). Streams within the IMP are quite diverse and there are few legal limits on their growth. One of these, inter-company transfers (ICTs), is not new, but it now extends beyond professional and managerial workers to more permeable and expansive categories. As a result, unions increasingly face the prospect of organizing workplaces where ICTs and other migrant workers are employed alongside permanent employees, raising difficult legal issues and strategic dilemmas. This article presents a detailed case study one union's response to this situation.
\end{abstract}

Keywords: migrant workers; intra-company transfers; labour mobility; trade unions; collective bargaining 


\section{Introduction}

The use of temporary foreign (migrant) workers ${ }^{2}$ in Canada has been a contentious political topic for several years, resulting in ongoing rounds of program revision ${ }^{3}$ and stimulating a large body of critical academic research across several disciplines, often done in partnerships with migrant worker activists. ${ }^{4}$ Seasonal agricultural workers, live-in caregivers and domestics, and other low-skill workers in what since 2014 are labelled the Temporary Foreign Worker Program (TFWP) have been the focus of this controversy and study. While there are good reasons for this attention, too narrow a focus on these workers (hereinafter referred to as TFWs) has left relatively unexamined a second category of migrant workers, in what since 2014 has been labeled the International Mobility Program (IMP). This is unfortunate because while the TFWP has been shrinking in size in recent years, the IMP has been rapidly expanding (MertinsKirkwood, 2015; Conference Board of Canada, 2016) and there is a significant likelihood that the number of IMP workers will continue to increase as Canada enters into new bi- and multilateral trade deals that facilitate this kind of labour mobility (Mertins-Kirkwood, 2016; Curry, 2015).

The IMP consists of a number of different programs, one of which is intra-company transfers (ICTs). ICTs are workers who have been employed in another country by a firm that also operates in Canada and who are temporarily transferred to the Canadian operation. This arrangement intersects with a phenomenon that David Weil (2014) has recently drawn attention to in his book, The Fissured Workplace. Weil's book examines the changing structure of employer organizations and its implications for employment conditions and the enforcement of labour rights. Essentially, by fissuring Weil refers to the phenomenon of employers shifting the boundaries of the firm inwards so that it reduces the number of workers who are under its direct control as employees. Instead, the firm meets its labour requirements by contracting with other entities through franchising, sub-contracting or extended supply chain arrangements to produce and sell goods and services under its brand name. The result is that responsibility for employees is also pushed outwards and diffused between multiple entities, often making it unclear which one is the legal employer or responsible for the employer's legal obligations.

Intra-company transfers can be understood to involve fissuring in two dimensions. The first is the fissuring employer responsibility because of a blurring of the lines of legal responsibility between the parent firm and the sending and receiving subsidiaries. As this case study demonstrates, it may be difficult to determine which of these entities is the legal employer. The other dimension of fissuring is at the level of workforce. By combine in one location workers with several different immigration statuses and types of employment contracts, produces organized disorganization that creates difficult collective action problems for workers. These problems are not unique to workplaces with migrant workers. There is, for example, a developing literature on the challenges involved in organizing workplaces with permanent and 
temporary help agency (THA) workers (Bartkiw 2012) and native born and immigrant workers (Bernsten and Lillie, 2016;Foster, 2016; Adler, Tapia and Turner, 2014; Alberti, Holgate and Tapia, 2013).

The CS Wind story brings these strands together. It involves a Korean parent company, which transfers production workers from in Vietnamese to its Canadian branch plant, where THA workers were also present. This was the situation confronting the Ironworkers Union when they were invited by the permanent Canadian workers to lead an organizing drive in the summer of 2012. The response of the employer, the strategy of the union and the resolution of the legal issues that arose before the Ontario Labour Relations Board (OLRB) are the subject of this paper and provide a window onto the changing landscape of Canadian labour mobility, its legal implications and the strategic dilemmas faced by unions.

\section{The Changing Landscape of Migrant Worker Programs in Canada}

There is no single migrant worker program in Canada. Rather, since its inception, beginning with the Seasonal Agricultural Worker Program in 1964, different programs have been created to respond to specific employer demands. In 1973 the government created the Non-Immigrant Employment Authorization Program (NIEAP), a more general temporary worker program that required prospective employers to obtain a a Labour Market Opinion (LMO - now called a Labour Market Impact Assessment (LMIA)) that Canadians are not available for these positions. Work authorizations tied temporary foreign workers to their particular employers. Within the NIEAP, separate streams developed, each with their own unique rules, including the Live-In Caregiver Program in 1981 and the low-skill program in 2002. Separate streams for highly skilled workers were also created (Fudge and MacPhail, 2009; Macklin 1994; Satzewich 1991).

The number of TFWs grew substantially over the turn of the twenty-first century. In 1995, there were about 14,000 TFWs in Canada at the end of the year, while in in 2009, the peak year, the number increased to over 112,000 (Citizenship and Immigration Canada, 2014: Table 1.1; Yalnizyan, 2015). This explosive growth raised concerns that employers were abusing the program to displace Canadian workers and/or create downward pressure on wages, particularly at the low end of the labour market (Gross, 2014). ${ }^{5}$ But most importantly, academics and advocates highlighted the vulnerability of TFWs to exploitation and the unfairness of denying most of these workers a pathway to permanent residency. The fact that since 2006 the number of temporary foreign workers in all programs exceeded the number of economic immigrants (Faraday, 2012: 10-11) only emphasized the point that Canada was moving away from its 
traditional policy of meeting labour market needs through permanent immigration toward a guest worker regime.

Because of the bad publicity generated by revelations of employer abuse of the TFWP and of the workers in them, as well as the effects of the recession, the number of TFWs obtaining permits annually declined from a peak of 128,384 in 2008 to 73,094 in 2015. However, this decline did not result in fewer annual authorizations for migrant workers. To the contrary, since 2008 the total number of annual signed authorizations has increased from 146,980 to 293,010 in 2014, although there was a decline to 249,765 in 2015 (calculated from Citizenship and Immigration Canada 2014 \& 2015). The growth in migrant workers came from the International Mobility Programs, which comprise a diverse set of programs that facilitate the ability of nonCanadians to work in Canada without having to obtain a LMIA. In 1995 there were less than 40,000 IMP workers present in Canada at the end of the year while in 2015 the number had grown to about 250,000 (See Figure 1, below).

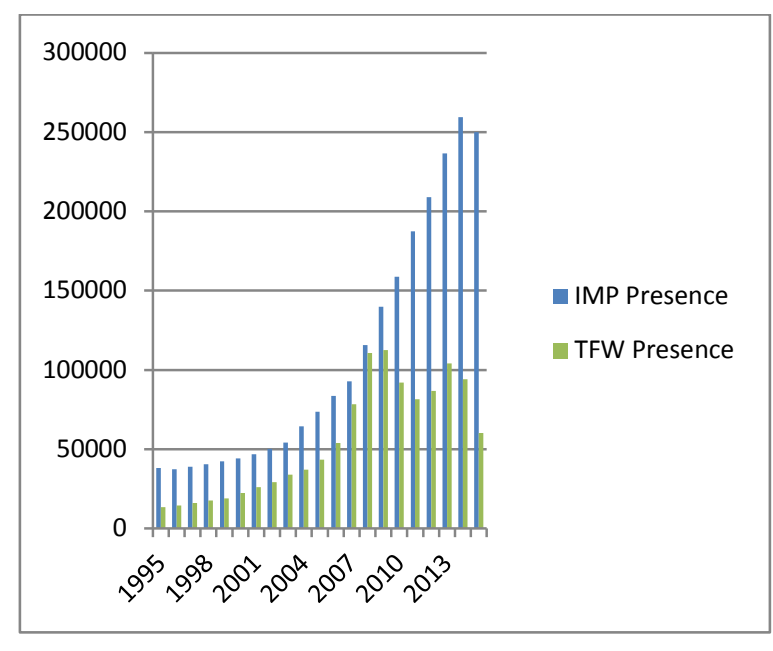

Figure 1.

Presence of TFWs and IMPs, 1995-2015.

Sources: Citizenship and Immigration, Canada

2014 and 2015

Table 1 below, prepared by the Canadian government, summarizes the principal differences between the two programs. 


\begin{tabular}{|c|c|}
\hline $\begin{array}{l}\text { Temporary Foreign Worker Program } \\
\text { Objective: Last resort for employers to fill } \\
\text { jobs for which qualified Canadians are not } \\
\text { available }\end{array}$ & $\begin{array}{l}\text { International Mobility Programs } \\
\text { Objective: To advance Canada's broad } \\
\text { economic and cultural national interest }\end{array}$ \\
\hline $\begin{array}{l}\text { - Based on employer demand to fill specific } \\
\text { jobs }\end{array}$ & - Not based on employer demand \\
\hline - Unilateral and discretionary & $\begin{array}{l}\text { - Based largely on multilateral/bilateral } \\
\text { agreements with other countries (e .g . } \\
\text { NAFTA, GATS) }\end{array}$ \\
\hline $\begin{array}{l}\text { - Employer must pass Labour Market Impact } \\
\text { Assessment (formerly LMO) }\end{array}$ & $\begin{array}{l}\text { - No Labour Market Impact Assessment } \\
\text { required }\end{array}$ \\
\hline - Lead department ESDC & - Lead department CIC \\
\hline - No reciprocity & - Based largely on reciprocity \\
\hline $\begin{array}{l}\text { - Employer-specific work permits (TFWs tied } \\
\text { to one employer) }\end{array}$ & $\begin{array}{l}\text { - Generally open permits (participants have } \\
\text { greater mobility) }\end{array}$ \\
\hline - Majority are low-skilled (i .e . farm workers) & - Majority are high skill / high wage \\
\hline $\begin{array}{l}\text { - Last and limited resort because no } \\
\text { Canadians are available }\end{array}$ & $\begin{array}{l}\text { - Workers \& reciprocity are deemed to be in } \\
\text { the national economic and cultural interest }\end{array}$ \\
\hline $\begin{array}{l}\text { - Main source countries are developing } \\
\text { countries }\end{array}$ & $\begin{array}{l}\text { - Main source countries are highly } \\
\text { developed }\end{array}$ \\
\hline
\end{tabular}

\section{Table 1.}

Comparison of Current Categories of TFWP and IMP.

Source: Employment and Social Development Canada, 2014: 1.

The IMP program is divided into two principal categories, Agreements and Canadian Interests. The Agreements category includes workers who are admitted pursuant to free trade (FT) and other international and federal-provincial agreements while the Canadian Interest category is a more diverse one which is divided into four sub-categories: significant benefit; reciprocal employment; competitiveness and public policy and charitable or religious. Intra-company transfers enter Canada through both branches of the IMP. A large percentage of Agreement workers enter Canada as ICTs pursuant to the North American Free Trade Agreement (NAFTA), which covers Canada, the United States and Mexico. The agreement permits U.S. and Mexican citizens who have been continuously employed for at least a year by an enterprise in their home country to temporarily transfer to a parent, branch, subsidiary or affiliate of that enterprise in Canada. They must be seeking employment in the Canadian operation in an executive, managerial or specialized knowledge capacity (Citizenship and Immigration Canada, 2014a). 
The maximum duration of the work permit is seven years for an executive or managerial employee and five years for a specialized knowledge worker. There is no limit on the number of NAFTA ITCs, and at the end of 2015 there were 23,292 such workers in Canada, the large majority from the United States. (Citizenship and Immigration Canada, 2015).

The other group of ICTs enter through the significant benefit sub-category of the Canadian Interests stream of the IMP. The governing provisions are similar to those applicable to NAFTA intra-company transfers, but apply more broadly to any person employed by a multinational company outside of Canada who is seeking to work for the parent, or a subsidiary, branch or affiliate of that enterprise located in Canada. The intra-company transferee must have been employed continuously for at least one year in the three year period preceding the application and be seeking to work in an executive, senior managerial or specialized knowledge capacity in Canada. Generally, the company must have established a continuing and legitimate presence in Canada and where specialized knowledge workers are involved the company must ensure that the work is guided and directed by management at the Canadian operation. Initial work permits are issued for one year but may be renewed for either seven years (executives and managers) or five years (specialized knowledge worker). The permits are tied to the employer, an occupation and a location. At the end of 2015 there were 17,755 IMP ICTs in Canada. The combined number of ICTs present in Canada was 41,047, or about 16\% of all IMP workers, making them the third largest category after competitiveness and public policy ${ }^{6}(122,823)$ and reciprocal employment $(61,612)$ (Citizenship and Immigration Canada, 2015).

The obvious question is whether the growth in the number of IMP workers generally or ICTs in particular should be worrisome for those who are concerned about the exploitation of temporary foreign workers and the impact of fissured workforces for workers' collective action. Sargeant and Tucker (2010) developed a multi-layered analysis for understanding the occupational health and safety vulnerabilities of temporary foreign workers which includes consideration of migration factors, migrant worker factors and receiving country factors. Without elaborating, the vulnerability structure of IMP workers is different than that of TFWs. In general, IMP workers have greater labour market mobility because their work permits are commonly more open, enabling them to work for any employer, although this is not true for ICTs whose work permits are tied to their employer and their occupational category. In regard to migrant worker factors, the majority of IMPs are higher skilled and are more likely to come from other developed countries than is the case for TFWs (Citizenship and Immigration Canada, 2014: 15). However, with regard to ICTs there has been a notable increase in the percentage who are specialized knowledge workers rather than executive or managerial. A special data run by Statistics Canada (2017) found the percentage in this group had grown from about 15\% in 1996 to 55\% in 2016. Of course, specialized knowledge workers range across a wide number of occupations, some of whom may be more vulnerable than others. Finally, IMP workers are more likely to be recruited into positions well above the bottom of the Canadian labour market, unlike many streams of the 
TFWP. Therefore, it is fair to conclude that in general greater concern for TFWs than for IMPs is still warranted, notwithstanding that their share of all temporary foreign workers in Canada is declining. However, the IMP is composed of many streams, which require separate evaluation to determine whether there are specific groups of workers for whom particular concern is warranted. $^{7}$ A comprehensive examination of the IMP and the vulnerabilities it produces is outside the scope of this article, but the following case study provides at least for some groups a “middling” level of concern (Brenda, 2003: 209) is warranted.

The issue of fissured workforces is tied to worker vulnerability insofar as it is vulnerable workers who most need the protection that collective action can provide. Although the Canadian research is thin, there is little doubt the presence of a significant number of temporary foreign workers produce a complex environment for collective worker action. Tucker and Jowett (2014) examined collective bargaining for TFWs in Canada and found in general there had been limited success organizing seasonal agricultural workers and workers in the low-skill stream. However, they also found that when TFWs were hired into workplaces that were already organized some unions negotiated collective agreement provisions that addressed these workers' particular needs, including arrangements that facilitated their path to permanent residence. Foster (2014; also Foster, Taylor and Khan, 2015) studied the response of Canadian unions to TFWs and identified three temporally sequential approaches or narrative arcs. The first, beginning 2006 when the influx of TFWs was rapidly increasing, was reactive and negative, denying there were local labour shortages and demonizing employers for using TFWs to drive down wages and avoid unions. The second, beginning in the middle of 2007, shifted its focus onto the vulnerability of TFWs, their exploitation by employers and the failure of government to monitor and protect. The third narrative, dating from the 2008 recession, constructed a dual narrative of protecting Canadian jobs while also being concerned for the plight of TFWs.

There is only one study of union organizing in the context of a workplace that employed both TFWs and permanent Canadian residents (Foster and Barnetson, 2010) and none that examine union organizing in a workplace with ICTs. The CS Wind story, therefore, provides a first look at the complexities that can arise in this situation.

\section{The CS Wind Story}

CS Wind Corporation is a global wind tower company...we create the bright future for human [sic] and nature ${ }^{8}$

The CS Wind story is a detailed case study of the attempt by the Iron Workers' union to organize the Canadian branch-plant of CS Wind Korea (CSWK) in Windsor, Ontario. The employer of the Canadian workers, CS Wind Canada (CSWC), fiercely resisted this effort and numerous legal disputes arose, leading the parties frequently to litigate before the Ontario Labour Relations Board (OLRB), which oversees Ontario's collective bargaining law. This resulted in many days 
of hearings with testimony from employer representatives, union organizers and supporters and ICTs from CS Wind's Vietnamese subsidiary (CSWV). The Vietnamese workers became involved in the litigation not because of any choice of their own, but rather because they were called as witnesses by CSWC. Their presence in the workplace created a strategic dilemma for the union and provided the employer with an avenue for trying to defeat the organizing drive. The story is told sequentially, beginning with the establishment of the Canadian branch plant and the contractual arrangements that governed the Vietnamese ICTs employment in Canada, followed by an examination of the decisions made by the union during the organizing drive and the resolution of the complex legal problems that arose as the employer and union maneuvered to determine the outcome of the organizing drive.

CSWK is a Korean-based company founded in 1989 as the Choong Sang Corporation. It built its first wind tower manufacturing plant in 2003 in Vietnam followed by a second facility China in 2006. Its sales of wind towers in North America grew and in 2011 it established CSWC and built a production facility in Windsor, Ontario, a rust belt border city that has suffered from severe job losses in manufacturing (Ryan, 2012). CSWC began assembling its labour force in 2011, including ICTs from CSWV, domestic hires and temporary help agency (THA) workers. With regard to the Vietnamese intra-company transfers, an application for visas and work permits was filed by CSWC in Ho Chi Minh City in September 2011. The stated reason for each visa was to provide training to Canadian workers regarding "the interpretation and the implementation of alternative energy technical fabrication and assembly processes; work flow and administration processes; and business systems, reporting requirements and customer interaction” (CS Wind, 2014: para 65). The application also stated that while on assignment in Canada, the Vietnamese workers would receive a monthly salary paid by CSWV in Vietnamese currency deposited to accounts in Vietnam, that the Vietnamese workers would continue to participate in CSWV health and benefit plans and that CSWV would be responsible for the workers' expenses, including accommodations and round-trip airfare. Salary levels would be consistent with Vietnamese salary levels, which ranged from \$140 a month at the low end, \$175 in the mid-range and up to $\$ 421$ for one worker at the high end. Income taxes were deducted and paid in Vietnam, as were union dues which were remitted to the Vietnamese union that represented them in Vietnam (CS Wind, 2014: para 76). ${ }^{9}$

The visa application was successful and work permits were issued. The permit authorized the workers to work for CS Wind at their stated occupation in the Windsor location. The permit holders were prohibited from attending any educational institution or taking any academic, professional or vocational training courses while in Canada. The visas were initially issued for either five or ten months. Ultimately thirty-one Vietnamese workers were transferred to CSWC by 2012, when production began, one group arriving in 2011 and another in 2012. CSWC arranged for them to be housed together, for their transportation to and from work and for lunches to be provided by a local Vietnamese restaurant. They were also provided with 
allowances for telephone, personal hygiene, laundry, meals and spending money. In April 2012, CSWC applied for and received one year extensions for those workers whose permits would be expiring in the near future. In that application, CSWC stated that the Vietnamese workers would be paid approximately $\$ 25$ per hour plus allowances and that CSWV would pay these amounts. Subsequent permit extensions were sought and obtained (CS Wind, 2014: paras 70, 75 \& 79).

The actual terms and conditions of the Vietnamese workers apparently varied from those stated in the visa applications and was the subject of testimony in the OLRB proceedings. It is apparent from the testimony that local management actually knew very little about what the Vietnamese workers were being paid. The clearest evidence of their actual terms of employment came from the testimony of three Vietnamese workers called by CSWC, Nguyen Van Long, Nguyen Huu Huong and Dang Van Vinh. Each worker was recruited by CSWV and promised they would be paid double their Vietnamese salary in Vietnamese currency deposited into a Vietnamese bank account which their families could access. They participated in CSWV's social and health insurance plan and were covered by the collective agreement between the Vietnamese union and CSWV. The OLRB calculated the actual pay of the Vietnamese workers in November 2012, which ranged between $\$ 950$ and $\$ 1,600$ Canadian a month, plus allowances of about $\$ 600$ a month. The OLRB found that the Vietnamese worked long hours, frequently more than 60 hours in a week, for which they were paid overtime in Vietnam (CS Wind, 2014: paras 80-97). Including salary and allowances, and assuming a forty hour week, the highest paid workers earned about $\$ 13.00$ an hour, slightly more than the minimum wage at the time which was $\$ 10.25$. However, once overtime hours are included, it is probable that all the Vietnamese workers were being paid less than the Ontario minimum wage. ${ }^{10}$

The number of THA workers employed in production and janitorial services at CSWC is unknown. However, according Joel Thibodeau, who started working at CSWC in January 2012 and became a lead organizer, most of those workers were on long-term assignment and hoped to, and many did, become permanent CSWC workers (Thibodeau Interview, 2016). No evidence was presented on their terms and conditions of employment. It is also not clear how many domestic production workers were employed by CSWC by the summer of 2012, but it was certainly over 200 (CS Wind, 2012b and 2013a). By then the Canadian workers were becoming increasingly dissatisfied with working conditions. There were weekly meetings with management, which promised improvements that were not made. Local managers seemed to lack decision-making authority. The company rejected a proposal to have an employee committee represent workers, while unhappiness over shift scheduling, differences in wage rates, and disciplinary practices grew. A number of workers got together, including Thibodeau, and decided to organize with Ironworkers, Local 721. ${ }^{11}$ Thibodeau became an active inside organizer and worked closely with Lash Ray, then the Ironworker's chief organizer (Thibodeau and Ray Interviews, 2016). 
From the outset the workers and the union had to consider who they were going to organize. It was clear that the THA workers would have to be included since under Ontario law it was very likely CSWC would be found to be their employer for collective bargaining purposes. The question of the Vietnamese workers was more complicated, both for practical and for legal reasons. At a practical level, although the Vietnamese workers worked alongside the domestic workers and also played a role in training, communication was limited since many of the Vietnamese workers had poor English language skills. As well, they were socially segregated and highly sequestered by the company: they lived together; they were transported to and from work together; had their lunches brought to them by the employer, etc. And last but not least, some of the domestic workers felt resentment toward the Vietnamese workers, which at one point manifested itself in an offensive posting on a Facebook page allegedly used for organizing purposes, which was subsequently removed (CS Wind, 2013: para. 15). Part of the resentment stemmed from the employer's claim that they needed the Vietnamese workers because local workers did not have the specialized knowledge and skill required to perform the work. Not only did this strike at the workers' sense of their own abilities, but as time wore on, the claim rang increasingly hollow and some viewed the Vietnamese workers as low wage competitors taking jobs that should have gone to unemployed workers in the Windsor area. When these feelings were overlaid on top of the multiple barriers that inhibited communication between the Vietnamese and the Canadian workers, building solidarity that would facilitate organizing was difficult (Thibodeau and Barnes Interviews, 2016). ${ }^{12}$ Further, as a legal matter, the Vietnamese workers had contracts of employment with CSWV, the terms of which were not clear even to local management. In these circumstances, organizers questioned whether it was legally or practically possible to include the Vietnamese workers in the bargaining unit and bargain on their behalf.

Notwithstanding the above, it would be overly simplistic to characterize the response of the Canadian workers and union organizers as reactive and negative, to use the categories developed by Foster (2014). Organizers also perceived that the Vietnamese workers were being exploited and paid significantly less than the Canadians and could benefit from being unionized. As a result, they made some effort to distribute union literature, previously translated into Vietnamese for an organizing drive at a different location where Vietnamese immigrants were employed. Lash Ray reports that organizers attempted to go to the building where the Vietnamese workers were housed but that they were turned away by a CSWC manager from Korea. On another occasion he reports an attempt was made to leave the translated literature in the lunch room but the organizer was reprimanded and the literature was removed. It is unknown whether any of this literature got into the hands of the Vietnamese workers, but it is certain that none of them tried to contact or join the union. Organizers suspected that the Vietnamese workers may also have been fearful that if they became involved with the union they would be sent home (Thibodeau and Ray Interviews, 2016). 
It is not entirely clear when the decision was made to focus exclusively on the Canadian workers, but it must have occurred fairly early in the organizing drive and was based on strategic considerations. Because none of the Vietnamese workers had joined the union, their inclusion in the proposed bargaining unit would have made it more difficult to reach the $40 \%$ threshold level of support necessary to trigger a certification vote. Moreover, even if the union passed the threshold, winning the election would have been more difficult since it was assumed that the Vietnamese workers might be mobilized by the employer to vote against the union. And finally, even if the union won the certification election for a more comprehensive unit, negotiating an agreement that addressed the concerns and interests of the Vietnamese workers, who were working pursuant to Vietnamese employment contracts and in Canada without a secure status, would have presented serious practical problems.

The organizing drive among the Canadian workers quickly gained momentum and the union filed a certification application on October 4, 2012. The proposed bargaining unit excluded "training personnel" which clearly referred to the Vietnamese workers. The employer responded to the application with three lines of attack. The first two were quite conventional. First, it alleged the union under- estimated of the number of employees in its proposed bargaining unit and therefore failed to reach the $40 \%$ membership threshold necessary to get a certification vote. Second, it challenged the union's proposed bargaining unit as not appropriate for collective bargaining because it excluded the Vietnamese ICT workers and others. The employer's third objection, however, was very unusual. It alleged that the exclusion of the Vietnamese workers was discriminatory and in violation of the province's Human Rights Code (1990). While normally human rights claims are adjudicated before the Human Rights Tribunal, the Labour Relations Act (1995) provides that if a union discriminates on a prohibited ground it cannot be certified as a bargaining agent to represent workers. The allegation therefore was of great concern to the union, not just because it offended their perception of themselves as fighters for social justice, but also because it would have been fatal to their certification application (CS Wind, 2012). The employer's claim, however, was not without its own ironies. After all, it was the employer that sequestered the Vietnamese workers and paid them lower wages for doing work that was supposedly more skilled than the work performed by the domestic employees. This was the beginning of the litigation mash-up that produced some very strange and upside down arguments.

The union was concerned about whether it had properly estimated the number of employees in its proposed bargaining unit and withdrew its application in order to give it time to recruit more members (CS Wind, 2012a). The employer's response also caused the union to rethink its approach to the Vietnamese workers. It prepared and translated into Vietnamese another document, "Your Rights in Canada” (Appendix A) which it attempted to distribute to the Vietnamese workers. The document advised the Vietnamese workers that they had the right to equal treatment without prejudice, to join a union, to be paid the same as someone doing the 
same work and to not perform unsafe work. It also offered the union's assistance in addressing rights violations or negotiating better terms and conditions of employment. The penultimate paragraph responded directly to the employer's allegation that the union discriminated:

CS Wind says we discriminate against the Vietnamese workers and that is not true. We wish for you to have what all members of the union have, good wages, benefits and a safe place to work.

The brochure concluded advising the Vietnamese workers that could call the Ironworkers in confidence and that a Vietnamese speaker would call them back.

It was also around this time that the union considered organizing the Vietnamese workers as a separate bargaining unit and distributed a third document, also translated into Vietnamese, headed "Warmest Welcome." The union advised the Vietnamese workers it wished to represent the interests of all workers at CS Wind and understood that the Vietnamese workers needed a union "even more than other workers at the CS Plant" because of their inability to work elsewhere:

The IRONWORKERS UNION know that workers from Vietnam have unique concerns and think Vietnamese workers should have their own union bargaining unit and union so that you are able to get your employer to address the workplace problems shared by workers transferred from Vietnam...

The only way the problems faced by Vietnamese workers transferred to Canada will get better is if you join together to form a union to demand change.

The Vietnamese workers were given the name of a Vietnamese member of the Ironworkers working for a different employer in the Windsor area who they could contact. It is unclear how much effort the union devoted to getting this literature into the hands of the Vietnamese workers and, given the difficulties identified previously, it is unlikely it reached them. In any event, no Vietnamese workers contacted the union.

On November 19, 2012 the union filed another certification application for a proposed bargaining unit that excluded "persons working pursuant to an intra-company transfer program and/or employees of CS Wind Vietnam." The employer responded to this application as it had to the first. The board deferred consideration of the employer's objections and ordered that an election be held on November 26. It defined the voting constituency broadly to permit all production employees to vote save and except persons above the rank of foreman. Disputed ballots were to be segregated and the ballot box would be sealed until the outstanding issues had been resolved (CS Wind 2012b). 
Before the certification election, the employer held a meeting with employees on a Sunday, which workers were paid to attend. At that meeting, Joel Thibodeau asked why the Vietnamese workers were being paid lower wages and were having their terms and conditions of employment dictated to them. CSWC's legal counsel, David McNevin's lengthy response castigated the union for seeking to carve the Vietnamese workers out of the bargaining unit (CS Wind, 2015: para 72). ${ }^{13}$ In the certification election 187 ballots were cast, of which 60 were segregated pending the outcome of various challenges.

Much litigation followed, including allegations of unfair labour practices leading up to and following the vote and of occupational health and safety reprisals (eg., CS Wind, 2013a \& 2015). These aspects of the case are not examined since they did not touch on the question of the Vietnamese ICTs. There was, however, the employer's allegation that the union had unlawfully discriminated against the Vietnamese workers and therefore had disqualified itself from being certified. The union challenged the employer's standing to bring the claim and challenged whether a prima facie case had been made out. In response, the employer alleged that a Facebook page used in the original organizing drive contained offensive comments about the Vietnamese workers and claimed that the union had made minimal efforts to translate its organizing materials during the membership drive that resumed after the first application was withdrawn. These claims were additional to the assertion that the exclusion of the Vietnamese workers from the proposed bargaining unit was itself discriminatory.

The board ruled that the Facebook allegation was too vague since it failed to identify the impugned comments or who had made them, but the Board did allow the employer to introduce evidence regarding the translation of written material and the bargaining unit description. However, the employer ultimately chose not pursue its human rights claim, leaving the position of the Vietnamese workers to be addressed on the basis of whether the union's proposed unit was appropriate for collective bargaining (CS Wind, 2013).

Given the large number of issues before the OLRB, it needed to decide on the order in which they would be considered and chose to start with the bargaining unit issue. A little labour law background is essential here. Ontario labour law requires a union applying for certification to define of the group of employees it wishes to represent. However, the labour board must find the union's proposed bargaining unit to be an appropriate one and the employer is given the opportunity to challenge the unit proposed by the union and suggest a different one. In recent years the OLRB has taken the view that the bargaining unit proposed by the union does not have to be the most appropriate one, based on some notion of what an ideal unit would be, but rather that the employees share a community of interest and that the unit that will not cause the employer significant industrial relations problems. However, there is a background condition that must be satisfied and that is that all members of the bargaining unit must be employed by the 
employer (Adams, 2017: 7.2). As a result, it had to be determined who was the employer of the Vietnamese workers for collective bargaining purposes, CSWC or CSWV. ${ }^{14}$

In many contexts, it is the named employer who argues it is not the legal employer in order to avoid the ensuing obligations. Here, however, the situation was reversed; CSWC was arguing that it was the legal employer of the Vietnamese workers, while the union was arguing that it was not and that they were employed by CSWV. As is often the case in litigation, these positions were taken for purely strategic purposes. For the CSWC, a finding that it was the employer was essential in order for it to be able to argue that the Vietnamese ITCs must be included in the bargaining unit, while for the union a finding that CSWV was the employer would preclude the Vietnamese workers from being in the bargaining unit. The downside of the union's position, however, was that if their argument succeeded the Vietnamese workers could not be certified as a separate bargaining unit either, although that was a remote prospect in any event.

Ontario uses a "comprehensive" test to determine the 'true' employer for the purposes of collective bargaining. The Supreme Court of Canada devised this test in the context of a case involving THA workers, where the question was whether the agency or the client was the employer for the purposes of collective bargaining (Pointe Claire 1997, para. 48).

According to this more comprehensive approach, the legal subordination and integration into the business criteria should not be used as exclusive criteria for identifying the real employer. In my view, in a context of collective bargaining...it is essential that temporary employees be able to bargain with the party that exercises the greatest control over all aspects of their work - and not only over the supervision of their day to day work....Without drawing up an exhaustive list of factors pertaining to the employeremployee relationship, I shall mention the following examples: the selection process, hiring, training, discipline, evaluation, supervision, assignment of duties, remuneration and integration into the business.

The OLRB reviewed the evidence in relation to these factors and found that the Vietnamese workers were hired and trained by CSWV and indeed had relatively long service with CSWV, some having previously worked stints at CS Wind's Chinese branch plant. The decision to send them to work at the Windsor branch plant was made by the head office in Korea, but the Vietnamese workers had been asked to go to Canada by their Vietnamese supervisors. The terms and conditions of their employment were made in Vietnam, including a retention bonus for each month they worked in Canada, as well as higher rates of pay. There was no evidence that CSWC had any role in setting their terms and conditions of employment. Indeed, local managers did not know the terms of the Vietnamese workers' contracts, even regarding what constituted regular hours of work or overtime, and their hours of work were separately recorded by a different system than the one used for the domestic workers. In terms of work, the OLRB found that the 
Vietnamese workers were doing the same work as the domestic workers, with the same tools and equipment, and reporting to the same supervisors and managers. They also generally worked in teams with the domestic workers.

Given this fissured responsibility structure, who exercised the greatest control over all aspects of the work? The answer is far from obvious, but the OLRB had to decide and it determined it was CSWC. The OLRB explained its conclusion in a brief paragraph (CS Wind, 2014: para 111).

It is CSWC which arranged their accommodation; their transportation to and from the plant; had meals delivered to the plant for them; paid them various cash allowances; directed their schedules and work; has made all arrangements for the extension of their work permits; and it seems that it will be CSWC which will ultimately determine when they can return to Vietnam. It is noteworthy that two of conditions of the work permits are that the Vietnamese Workers must continue to work for CSWC and at the Windsor plant.

Notwithstanding this conclusion, later in its judgment the OLRB emphasized the significance of the fact that these workers' terms and conditions of employment were set in Vietnam for the purposes of collective bargaining (CS Wind, 2014: paras138-39).

Even though, for the purposes of this application, the Board has found that CSWV is not the employer of the Vietnamese Workers, the practical reality appears to be that CSWV plays a major role in their terms and conditions of employment. However, the Union would not have that company at the bargaining table and have no legal means of getting it to participate in negotiations.

Even if the Union is able to conclude a collective agreement for a bargaining unit that included both types of workers, it argued that it would have no practical means of enforcing wage payments of health insurance benefits in Vietnam. If a Vietnamese worker was disciplined or terminated from employment and therefore returned to Vietnam with the consequent loss of a work permit, the Union would have no way to get the worker back to Canada for grievance arbitration, or in the event of a reinstatement, would not be able to enforce the remedy.

In any event, based on its finding that CSWC was the true employer, the board then turned its mind to question of a bargaining unit that excluded the Vietnamese workers was an appropriate one. The employer's claim that such a bargaining unit unlawfully discriminated on the basis of ethnic origin had been dropped by this point, so the matter was addressed from a conventional industrial relations perspective, which focuses on whether the employees share a sufficient 
community of interest and whether the proposed unit would cause the employer serious industrial relations problems (Hospital for Sick Kids, 1985).

Ironically, the employer argued that the two groups shared a community of interest because the Vietnamese and domestic workers performed the same work and had the same skill set, even though the Vietnamese workers were more highly skilled because of their greater work experience. This position was accepted by the board, notwithstanding that it was somewhat at odds with the employer's justification for the work permits -- that the Vietnamese workers were needed to train Canadian workers who lacked the skill to perform the job. However, the board ultimately concluded there was no community of interest between the domestic and the Vietnamese workers because of the differences in the levels and types of compensation and allowances and because the Vietnamese workers were only in Canada temporarily. "As such their expectations or interests are perforce going to be quite different from those of domestic workers who have long-term employment interests” (CS Wind, 2014: para 123).

The board was also sympathetic to the union's claim that it would be hard-pressed to meet its duty of fair representation to the 31 Vietnamese workers and the approximately 160 domestic workers (CS Wind, 2014: para 124 \& 128).

The union would have no real way of addressing the fact that the majority of the bargaining unit would not share the same interests or terms and conditions of employment. The Board has to be mindful of a union's ability to bargain for a viable unit and it is understandable that the competing interests of these two groups go well beyond the usual issues between groups of workers.

If the Vietnamese Workers are included in the bargaining unit, it will be difficult for the Union to bargain for this balkanized group in light of their different terms and conditions of employment and security of tenure with the employer.

With regard to the question of whether excluding the Vietnamese workers from the bargaining unit would generate serious labour relations problems for the employer, the Board was cognizant that the employer had structured the workforce as it had for its own purposes (CS Wind, 2014: para127).

...CSWC has apparently structured the workplace to meet its production needs, and has availed itself of the Temporary Foreign Worker program to bring 31 Vietnamese Workers to Windsor to both train and to supplement its domestic workforce until the domestic workers have been trained to the employer's satisfaction. As such, it has organized the workplace as it finds administratively convenient for its production purposes....CSWC has thus created a fractured workforce in which there are a large number of permanent 
domestic workers, and a smaller, but not insignificant number of temporary foreign workers, all of whom are doing essentially the same work.

In short, it found that the employer "has structured its workforce with the very division which it wishes the Board to ignore.” To emphasize the point, the OLRB noted that while the federal government's immigration policy mandated that intra-company transfers did not have the same labour market or job mobility as Canadian workers, it had been the choice of CS Wind to provide the Vietnamese workers with different terms and conditions of employment than its other production workers (CS Wind, 2014: para 132 \&138).

Finally, perhaps to address the earlier allegations made by the employer that the union had unlawfully discriminated against the Vietnamese workers by excluding them from the proposed bargaining unit, the OLRB explicitly stated that the basis for its determination that the union's proposed unit was appropriate was the large difference in the circumstances of the two groups of workers and the difficulties this would cause the union, and not because of the Vietnamese workers' national origin or immigration status (CS Wind, 2014: para 146).

While this is the end of the story for our purposes, the decision in this case did not resolve the certification application, but merely allowed the ballots to be counted and defined the bargaining unit for which the union needed to demonstrate majority support. The union lost the election but had earlier filed unfair labour practice complaints alleging that the employer had engaged in unlawful actions that prevented the employees from expressing their true wishes. After lengthy hearings, the OLRB upheld the union's complaint and determined that a remedial certification was the appropriate remedy in the circumstances (CS Wind, 2015; Thompson, 2015). Early in 2016 the union and the employer reached a first collective agreement (Battagello, 2016). By then, the Vietnamese intra-company transfer workers were gone, so even if they had been included in the bargaining unit, they would not have benefited from the collective agreement.

\section{Conclusion and Reflections}

The rapid growth in the use of migrant workers in Canada attracted much critical attention, largely focused on the TFWP and particularly its lower-skilled streams. However, as this article demonstrates, an overly narrow focus on these particularly vulnerable workers may leave unexamined new and growing streams of migrant workers under the International Mobility Program. While this program is quite diverse, researchers need to more carefully assess particular sub-groups and, where appropriate, make visible their labour market vulnerabilities. As well, and particularly for vulnerable migrant workers, it is important to consider the implications of and responses to workplace and workforce fissuring for both migrant and nonmigrant workers. 
Intra-company transfers are not a new form of labour mobility in Canada, but until fairly recently the number of workers involved was relatively small and most were professionals and executives. The rapid growth in the number of ICTs through both the Agreements and the Canadian Interests branches of IMP and the possibility of continued expansion, is good reason to scrutinize this stream more closely. While the program is currently restricted to workers in high skill categories, its boundaries are permeable and the situation that arose at CS Wind could become more common, although that will be determined by the response of the federal government to political pressure.

On the one hand, the Canadian government was responsive to concerns about the potential to exploit the specialized knowledge worker category to transfer lower skilled workers as ICTs. As a result, it introduced more rigorous assessment criteria for determining who qualified under this heading. This included a requirement that applicants establish on a balance of probabilities that the worker possesses a high standard of specialized knowledge, including both company specific and advanced expertise. As well, at least for non-NAFTA ICTs, the government states it will examine the wage currently being paid, expecting to see an above average salary that reflects the worker's specialized knowledge (Citizenship and Immigration Canada, 2014c). This may have contributed to a decline in the number of ICTs entering Canada since its peak in 2013, including a reduction in the number of specialized knowledge workers (Statistics Canada, 2017).

On the other hand, future trade agreements could open up the categories of workers permitted to enter as ICTs or in other IMP categories. For example, while the main text of the TPP contains fairly general language about temporary entry for business people, including ICTs, Canada's schedule of specific country commitments in Annex 12-A is quite expansive. In addition to investors, business visitors and ICTs (including a broadly defined sub-category of specialists), Canada also agrees to admit on a temporary basis listed "professionals and technicians” on a party by party basis. The definitions for these groups include workers engaged in occupations that have a National Occupational Classification skill level of O (Managerial), A (Professional) or B (Technical). The inclusion of workers with skill level B expands upon previous trade agreements which were limited to workers from skill levels $\mathrm{O}$ and $\mathrm{A},{ }^{15}$ and includes a wide range of listed occupations, such as contractors and tradespeople in various fields. Moreover, these workers are not ICTs who must have been employed by a subsidiary or parent, but may be hired by any Canadian company (Mertins-Kirkwood, 2016; Trans-Pacific Partnership Agreement, 2016: Annex 12-A). Although the future of the TPP is now in doubt, even if it does not come into force it could provide a template for future bi-lateral or multi-lateral trade agreements governing labour mobility.

The article also makes visible the legal and strategic difficulties unions face when attempting to organize workplaces with migrant workers generally and intra-company transfers in particular. As noted, the legal arguments in CS Wind were upside down: CSWC initially alleged that the 
union was unlawfully discriminating against the Vietnamese workers, when it was the party directly and most obviously responsible for the differential treatment; that it was the legal employer when it is far more common for companies to argue they are not the legal employer in order to avoid the legal responsibility for workers; and that a more inclusive bargaining unit should be required when its underlying goal was union avoidance, not more effective and efficient collective bargaining. The union's arguments were also upside down. Its claim that the Vietnamese workers' legal employer was CSWV would have deprived these workers of the benefit of much of Ontario's protective labour and employment laws and the argument that temporary foreign workers could be excluded from the bargaining unit impeded their access to unionization, undermining the broad worker solidarity on which industrial union strength is based.

Of course, these legal positions were primarily driven by short-term tactical considerations: the employer wanted to prevent its production workforce from unionizing; the union wanted to improve its odds of organizing a new bargaining unit. While the situation did not present a strategic dilemma for the employer, who was singularly interested in union avoidance, it posed a difficult dilemma for the union, which is not easily resolved. On the one hand, the union has an interest in organizing bargaining units that it can get certified by winning majority support. To achieve that goal, the union may seek to exclude groups of workers that it finds particularly difficult to reach or convince of the merits of unionization or who the majority of employees may resent. On the other hand, unions should be and often are quite concerned about the exploitation of vulnerable workers generally and of migrant workers in particular. How can and should unions respond when the achievement of their shorter-term organizing objectives conflict with their longer-term interest in building inclusive solidarity?

To a significant extent, these strategic dilemmas are produced by the underlying structures of collective bargaining regimes. The function of trade unions in North American collective bargaining regimes is narrowly representational as opposed to regulatory (Ewing 2005). As a result, to gain representational rights unions must organize enterprise or sub-enterprise bargaining units. This arrangement requires them to make a strategic decision about which workers can be successfully organized, and thus arises the problem of whether to include TFWs who may be more difficult to recruit. But, as well, they also need to make some legal judgments. First, they need correctly to identify the employer of the workers they wish to organize, taking into account that in a fissured workforce, not all employees will have the same employer. Second, because North American regimes do not permit unions unilaterally to determine the group of workers they wish to represent, unions must also make a legal assessment of whether their preferred group ey choose will constitute an appropriate bargaining unit in the eyes of a labour board that is also required to consider the employer's interests. 
To date, Canadian labour boards have only dealt with a small number of cases involving temporary foreign workers and CS Wind is the first instance in which it had to consider the specific situation of ICTs. Most of its previous judgments have involved seasonal agricultural workers (Tucker and Jowett, 2014). With regard to the question of the legal employer, labour boards have rejected arguments by farm owners that they are not the employer of SAWs because many terms and conditions of their employment are established by the inter-governmental agreements.

With regard to appropriate bargaining units, the issue has rarely arisen, in part because most certification applications have been for units comprised entirely of SAWs, and farmers have rarely argued that the proposed unit is inappropriate because it failed to include their Canadian employees, where such workers are present. In the one case an employer did make that argument the board rejected it on the basis that the terms and conditions of the SAWs were sufficiently distinct to justify separate certification (Sidhu, 2010). ${ }^{16}$ The bargaining unit issue also became contentious in Quebec when its collective bargaining law only allowed agricultural workers to organize if the employer hired at least three year-round employees. Under this regime, the labour board approved both separate and combined bargaining units. ${ }^{17}$

The emerging legal framework points to likelihood that Canadian firms using temporary foreign workers, including intra-company transfers, will be found to be their employers, but unions will be able to choose whether or not to include temporary foreign workers, including intra-company transfers, in the bargaining units they attempt to organize since either configuration is likely to be found appropriate. Thus, while the structure of the law creates strategic dilemmas, it does not resolve them one way or another. Unions must still decide how to proceed.

Of course, in principle unions should seek inclusive bargaining units. This would give temporary foreign workers terms and conditions of employment comparable to those of domestic workers, including protection against unjust discipline and discharge for the duration of their work permits. As well, unions then have the opportunity to negotiate contract provisions to address some specific vulnerabilities resulting from these workers' precarious immigration status. For example, special remedies, such as liquidated damages, could be negotiated to deter employers from wrongfully repatriating workers or to properly compensate those who are.

But it is not enough to espouse principles if the obstacles that stand in the way of their realization are formidable and very unlikely to be overcome. The Ironworkers clearly faced a very tough situation: the Vietnamese workers were difficult to reach because of language, cultural and employer-created barriers; their temporary status reduced the potential benefits of unionization while increasing the their vulnerability to employer retaliation; and Canadian worker support for their inclusion could not be taken for granted. Moreover, even if the union had succeeded in organizing an inclusive bargaining unit it is not obvious that it would have been able to negotiate 
more favourable arrangements for the Vietnamese workers without putting their continued employment in Canada at risk.

Finally, there is the question of the preferences of the Vietnamese workers. They had returned to Vietnam by the time this research was conducted and so there was no opportunity for them to be interviewed. There is also little we can infer from the fact that they never responded to the union's outreach efforts. Did they have no interest in being a part of the union; did they not feel welcomed; or did they fear employer retaliation? Three Vietnamese workers were called by CSWC to testify before the OLRB about their recruitment in Vietnam, the terms of the Vietnamese contracts they signed terms and the work they performed in Ontario, but they were not, and could not have been, asked about their attitude toward unionization and in any event this was hardly a setting in which they could have expressed their 'true' wishes.

So what is to be done? There are no easy answers within the parameters of the North American system of enterprise certifications and collective bargaining. In principle, these strategic dilemmas could be reduced in a labour law regime that assigned unions a regulatory role, establishing terms and conditions at a sectoral level that benefit all workers employed in the sector. In such a regime, unions would not have to organize bargaining units taking into account whether a particular group of workers was organisable while correctly identifying the employer and properly assessing whether their chosen bargaining unit would be found to be appropriate.

However, regulatory bargaining systems that exist solely at a national scale may not resolve the problem if the law permits the migrant worker to remain classified as the employee of their home employer. In this situation, the ICT would remain outside the sectoral agreement, resulting in labour market vulnerability and producing fissured workforces. This is the problem that confronted European Union (EU) members and led to the 1996 Posted Workers Directive. The Directive contemplates that posted workers will remain the employees of the sending company and so are subject to the sending countries laws. However, to avoid social dumping, the Directive provides that posted workers are entitled to a set of core rights in the host Member state including minimum wages and maximum hours of work laws, among others (Posted Workers Directive, 1996). Controversial interpretations of the Posted Workers Directive have reduced this floor of rights but recently a reform measure was presented by the European Commission that would entitle posted workers to equal pay and working conditions as local workers (European Commission, 2016). The Directive does much less to protect collective bargaining rights. Indeed, the European Court of Justice infamously held that collective bargaining agreements are a potential barrier to trade so that unions are severely limited in the actions they can take to enforce their terms in regard to posted workers (Davies, 2008). Moreover, to the extent that enterprise bargaining displaces sectoral bargaining, the Directive does not adequately deal with the situation of posted workers who are inserted into a non-union setting and how their presence might affect the acquisition of bargaining rights. 
In sum, while many ICTs are high level executives and managers for whom their temporary transfer is a stepping stone to advancement, the boundaries of this migrant worker are permeable and liable to expand to include lower skilled and vulnerable workers. When this occurs, as in the case of CS Wind, the result is fissured employers and fragmented workforces. In this context, it is a challenge to insure that ICTs and other migrant workers receive adequate social protection and have access to effective collective representation. Labour clauses in trade agreements are unlikely to provide much protection (Tham and Ewing 2016). The application of local employment law to ICTs and other TFWs goes some distance towards meeting these goals, however, where collective bargaining regimes assign unions a representational function, and unions must gain representation rights at the enterprise level they face strategic dilemmas over the incorporation of temporary foreign workers into bargaining units. These dilemmas are reduced where unions exercise a regulatory function, but unless the condition of ICTs and other migrant workers is effectively addressed at a transnational scale, the problems of fissuring and fragmentation are likely to recur.

Legal arrangements are thus responsible for the structures that produce strategic dilemmas and unions must grapple with the hand they have been dealt. The outline of a principled approach is clear: inclusive organizing and bargaining should be the union's goal, but conditions on the ground, may limit what can be achieved, even when unions make a serious effort to involve ICTs and other migrant workers. This case study epitomizes the strategic dilemmas that the Canadian collective bargaining regime creates, but, dare I say, the answers to those dilemmas are not blowing in CS Wind.

\section{References}

Adams GW Canadian Labour Law available at WestlawNext Canada.

Adler LH, Tapia M and Turner L (eds.) (2014) Mobilizing Against Inequality: Unions, Immigrant Workers, and the Crisis of Capitalism. Ithaca: ILR Press.

Alberti G, Holgate J and Tapia M (2013) Organising migrants as workers or as migrant workers? Intersectionality, trade unions and precarious work. International Journal of Human Resource Management 24(22): 4132-4148.

Anner M and Liu X (2016) Harmonious unions and rebellious workers: a study of wildcat strikes in vietnam. Industrial and Labor Relations Review 69(1): 3-28.

Bartkiw T (2012) Unions and temporary help agency employment. Relations Industrielles. 67(3): 453-476. 
Battagello B (2016) CS wind workers reach contract agreement. Windsor Star, 1 Feb.

Bernsten L and Lillie N (2016) Hyper-mobile migrant workers and dutch trade union representation strategies at the eemshaven construction sites. Economic and Industrial Democracy 37(1): 171-187.

Brenda SA, et al (2003) Introduction: transnationalism and its edges. Ethnic and Racial Studies 26(2): 207-217.

CIC News (2016) "Parliamentary Committee Recommends 21 Changes to Temporary Foreign Worker Program”(21 Sept. 2016). Available at http://www.cicnews.com/2016/09/parliamentarycommittee-recommends-21-changes-to-temporary-foreign-worker-program-098523.html.

Citizenship and Immigration Canada (2014) Facts and figures 2014, immigration overview temporary residents, table 1.1. Available at: http://open.canada.ca/data/en/dataset/052642bb3fd9-4828-b608-c81dff7e539c?.ga=1.66323245.2003443732.1459441894;

Citizenship and Immigration Canada (2014a) International mobility program: north american free trade agreement. Available at: http://www.cic.gc.ca/english/resources/tools/temp/work/international/nafta.asp.

Citizenship and Immigration Canada (2014b) Operational bulletin 575 (9 June 2014). Available at http://www.cic.gc.ca/english/resources/tools/temp/work/opinion/transferees/knowledge.asp

Citizenship and Immigration Canada (2015) Fact and figures 2015, immigration overview temporary residents facts and figures. Available at: http://open.canada.ca/data/en/dataset/052642bb-3fd9-4828-b608c81dff7e539c?.ga=1.113705473.700410561.1483469972.

Conference Board of Canada (2016) A Primer on Canada's Foreign Workers. Available athttp://www.conferenceboard.ca/e-library/abstract.aspx?did=8168 .

CS Wind Canada Inc. 2012, [2012] O.L.R.D. No. 3574.

CS Wind Canada Inc. 2012a [2012] O.L.R.D. No. 3576.

CS Wind Canada Inc. 2012b [2012] O.L.R.D. No. 4241.

CS Wind Canada Inc. 2013 [2013] O.L.R.D. No. 2641. 
CS Wind Canada Inc. 2013a [2103] O.L.R.D. No. 3372.

CS Wind Canada Inc. [2014] O.L.R.D. No. 621.

CS Wind Canada Inc. [2015] O.L.R.D. No. 1668.

Curry B (2015) TPP text raises concerns over regulation of temporary foreign workers. Globe and Mail, 6 November, 2015.

Davies ACL (2008) One step forward, two steps back? the viking and laval Cases in the ECJ Industrial Law Journal 37(2): 126-148.

Nakache D and Dixon-Perera L (2015) Temporary or transitional?: migrant workers' experience with permanent residence in Canada. IRRP Study, No. 55. Available at http://irpp.org/wpcontent/uploads/2015/10/study-no55.pdf.

Employment and Social Development Canada, Overhauling the Temporary Foreign Worker Program (2014) available at http://www.esdc.gc.ca/eng/jobs/foreign_workers/reform/overhauling_TFW.pdf.

European Commission (2016) News (08 March 2016). Available at http://ec.europa.eu/social/main.jsp?langId=en\&catId=89\&newsId=2488\&furtherNews=yes.

Ewing K D (2005) The function of trade unions Industrial Law Journal 34(1): 1-22.

Faraday F (2012) Made in Canada: how the law constructs migrant workers' insecurity. Metcalf Foundation. Available at http://metcalffoundation.com/wp-content/uploads/2012/09/Made-inCanada-Full-Report.pdf.

Faraday F (2014) Profiting from the precarious: How recruitment practices exploit migrant workers. Metcalf Foundation. Available at http://metcalffoundation.com/wpcontent/uploads/2014/04/Profiting-from-the-Precarious.pdf.

Foster J (2014) From 'Canadians first' to 'workers unite': evolving union narratives of migrant workers. Relations Industrielles 69(2): 241-265.

Foster J and Barnetson B (2010) Justice for janitors in Alberta: the impact of temporary foreign workers on an organizing campaign. Journal of Workplace Rights 16(1): 3-29. 
Foster J, Taylor A and Khan C (2015) The Dynamics of union responses to migrant workers in Canada. Work, Employment and Society 29(3): 409-426.

Fudge J and McPhail F (2009) The temporary foreign worker program in Canada: an extreme form of flexible labor. Comparative Labor Law and Policy Journal 31: 101-139.

Gross D (2014) Temporary foreign workers in Canada: are the really filling labour shortages. C.D. Howe Institute. Commentary No. 407, April 2014.

Hospital for Sick Children, 1985 CanLII 899 (ON LRB).

Human Rights Code, R.S.O. 1990, H. 19.

Human Rights Watch (2009) Not Yet a Workers' Paradise. Available at https://www.hrw.org/sites/default/files/reports/vietnam0509webwcover.pdf.

Labour Relations Act, 1995, S.O. 1995, c. 1, Sched. A, s. 15

Lenard PT and Straehle C (eds) (2012) Legislated Inequality. Montreal and Kingston ON: McGill-Queen's University Press.

Macklin A (1994) On the Inside Looking In: Foreign Domestic Workers in Canada. In Giles W and Arat-Koç S (eds) Maid in the Market: Women's Paid Domestic Labour. Halifax: Fernwood, pp. 13-30.

Marsden S (2011) Assessing the regulation of temporary foreign workers in Canada Osgoode Hall Law Journal 49(1): 39-70.

Mertins-Kirkwood H (2015) The Hidden Growth of Canada’s Migrant Workforce. In: Healy T and Trew S (eds) The Harper Record 2008-2015 . Ottawa: CCPA, pp. 149-58.

Mertins-Kirkwood H(2016) Migrant Workers and the Trans-Pacific Partnership. CCPA. Available at:

https:/www.policyalternatives.ca/sites/default/files/uploads/publications/National\%20Office/201 6/04/Migrant_Workers_and_the_TPP.pdf.

Pointe-Claire (City) v. Québec (Labour Court) [1997] SCR 1015. 
Posted Workers Directive (1996) Directive 96/71/EC of the European Parliament and of the Council of 16 December 1996 concerning the posting of workers in the framework of the provision of services.

Robertson S (2014) Time and temporary migration: the case of temporary graduate workers and working holiday makers in Australia. Journal of Ethnic and Migration Studies 40(12): 19151933.

Ryan B (2012) From Cars to Casinos: Global Pasts and Local Futures in the Detroit-Windsor Transnational Metropolitan Area. In: Chen X and Kanna A (eds) Rethinking Global Urbanism: Comparative Insights from Secondary Cities. New York: Routledge, pp. 91-106.

Sargeant M and Tucker E (2010) Layers of vulnerability in occupational health and safety for migrant workers: case studies from Canada and the UK. Policy and Practice in Occupational Health and Safety 7(2): 51-73.

Satzewich V (1991) Racism and the Incorporation of Foreign Labour. London: Routledge.

Sidhu \& Sons Nursery Ltd. v. United Food and Commercial Workers International Union, Local 1518, (2010) No. B26/2010 [Leave for Reconsideration denied in No. B64/2010].

Statistics Canada (2017) Canada - International Mobility Program (IMP) Work Permit Holders as Intra-Company Transferees by Skill Level, Intended Occupation (2-digit NOC 2011) and Year in which Permit(s) became effective, 1996-November 2016 (Special Run).

Tham J-C and Ewing K (2016) Labour clauses in the TPP and TIPP: A comparison without a difference? Melbourne Journal of International Law 17: 1-35.

Thompson C (2015) CS wind employees unionize after years of health and safety concerns. Windsor Star, 4 June, 2015.

Trans-Pacific Partnership Agreement (2016). Available at https://www.mfat.govt.nz/en/aboutus/who-we-are/treaties/trans-pacific-partnership-agreement-tpp/text-of-the-trans-pacificpartnership.

Tucker E and Jowett B (2014) Employment-related geographic mobility and collective bargaining in Canada. On the Move Partnership. Available at http://digitalcommons.osgoode.yorku.ca/cgi/viewcontent.cgi?article=1261\&amp;context=all_pa pers. 
Weil D (2014) The Fissured Workplace. Cambridge MA: Harvard University Press.

Yalnizyan A (2015) Canada can't let labour mobility create an underclass of TFWs. Canadian Centre for Policy Alternatives, Behind the Numbers 16 Oct. 2015 available at http://behindthenumbers.ca/2015/10/16/canada-cant-let-labour-mobility-create-an-underclassof-tfws/.

\section{Interviews by Author}

Ben Barnes, Lawyer representing Iron Workers (23 March 2016)

Lash Ray, Union Organizer (30 March 2016)

Joel Thibodeau, Union Organizer (23 March 2016) 


\section{Endnotes}

${ }^{1} 1$ This paper is written with the support of the On the Move Partnership, which is a project of the SafetyNet Center for Occupational Health and Safety Research at Memorial University. It is supported by the Social Sciences and Humanities Research Council through its Partnership Grants funding opportunity, the Research and Development Corporation of Newfoundland and Labrador, the Canada Foundation for Innovation and multiple universities and community partners across Canada and elsewhere. Thanks to Mary Hurley for her research assistance, Alec Stromdahl for his editorial assistance and Jason Foster for comments on an earlier draft.

2 A note on terminology is required. Migrant worker is a broad category that is variously used to describe immigrant workers who have the right to stay in where they have located and workers whose immigration status is temporary and who will be required to leave when their work permit expires. In Canada, the common term for these temporary workers was, until recently, "temporary foreign workers." However, in 2014 the Canadian government formalized a distinction between two types of temporary foreign work programs, one called the Temporary Foreign Workers Program (TFWP) and the other the International Mobility Program (IMP). To avoid confusion, in this paper I use the term migrant worker (in its narrower sense) to describe all temporary foreign workers, while reserving the term temporary foreign worker (TFW) for those in the TFWP.

3 The current federal Liberal government appointed a Parliamentary committee to review the Temporary Foreign Worker program in February 2016. In September it recommended 21 changes. As of the date of writing, no action has been taken (CIC News, 2016). The previous Conservative government introduced major reforms in 2014 (Employment and Social Development, 2014).

4 The literature is voluminous. For a small sample, see Nakache and Dixon Perea 2015; Faraday 2014; Lenard and Straehle 2012; Marsden 2011; Sargeant and Tucker 2010; Fudge and McPhail 2009.

5 Mark Carney, then Governor of the Bank of Canada testified before the House of Commons that "One doesn't want an over-reliance, certainly, on temporary foreign workers for lowerskilled jobs, which prevent the wage adjustment mechanism from making sure that Canadians are paid higher wages, but also so that firms improve their productivity as necessary...." Canada, House of Commons, Finance Committee, Meeting 115, (23 April 2013).

6 The majority of workers in this category hold work permits for post-graduate employment followed by spouses of skilled workers.

7 For example, the reciprocal employment group, the second largest category of IMPs, consists of young workers who are able to work in Canada through the International Experience Canada program, which consists of 32 bilateral agreements that provide young people with the opportunity to work and travel abroad. Their experience in Canada has not been studied, but research in Australia (Robertson 2014) suggests they may be highly vulnerable to exploitation. 
8 Retrieved from the front page of the CS Wind website at http://www.cswindcorp.com/eng/company/01_overview.asp.

9 Most trade unions in Vietnam are led by the Communist Party and lack independence, although this may be changing (Anner \& Liu 2016; Human Rights Watch 2009).

10 According to records obtained through a freedom of information request, a complaint was received by the Employment Standards Branch of the Ministry of Labour alleging minimum wage and hours of work violations for 31 workers. The source of complaint is not revealed, but there can be little doubt that the complaint was in reference to the 31 Vietnamese ICTs then working as CS Wind. An Employment Standards Officer conducted an investigation and found monetary violations (the amount is unknown), presumably indicating that the Vietnamese workers were being paid less than the minimum wage or not being paid for their overtime hours, or both. CS Wind paid the amount owing so no monetary order was issued. However, a compliance order was issued with respect to record keeping. A re-inspection was conducted a year later which found violations in relation to written agreements regarding vacation periods.

11 The full name of the union is International Association of Bridge, Structural, Ornamental and Reinforcing Ironworkers, Local 721.

12 Thibodeau testified at the labour board that both the use of TFWs and agency workers had been issues in the campaign, particularly about agency workers not being hired on directly by CSW (CS Wind 2015, para. 80).

13 This was followed by a scandalous and unfounded claim by McNevin that Thibodeau tried to parlay his organizing into a supervisory position. The OLRB characterized McNevin's charge as an attempt to undermine the union on the eve of the election and an unfair labour practice (CS Wind 2015, paras. 77-78, 12).

14 A third possibility, not proposed by either party, was that the employer was CSW Korea, but it is extremely unlikely that the labour board would have found that to be the case even if that option had been put on the table.

${ }^{15}$ For example, NAFTA covers American and Mexican business people engaging in business activities at a professional level, which is reflected in the list of covered occupations in NAFTA Appendix 16.03.D.1.

16 In that case, the board restricted the scope of the union's bargaining rights so that it could only negotiate over those terms and conditions that were unique to the SAWs.

17 The condition that there had to be three permanent employees in order for agricultural workers to become unionized was successfully challenged as an unconstitutional infringement of freedom of association. However, this did not turn out to be helpful for SAWs on farms without permanent workers because the government responded by creating a special and very weak 
regime for making collective representations for workers in this situation (Tucker and Jowett, 2014: 47-48). 